\title{
Comparison of ankylosing spondylitis patients with and without fibromyalgia syndrome according to the disease activation scores and response to treatment
}

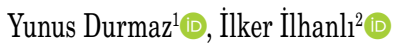 \\ ${ }^{1}$ Department of Physical Medicine and Rehabilitation, Division of Rheumatology, Karabük Training and Research Hospital, Karabük, Turkey \\ ${ }^{2}$ Department of Physical Medicine and Rehabilitation, Medicine Faculty of Ondokuz Mayıs University, Samsun, Turkey
}

Received: November 19, 2020 Accepted: March 10, 2021 Published online: December 01, 2021

\begin{abstract}
Objectives: The aim of this study was to investigate the association of fibromyalgia (FM) syndrome with ankylosing spondylitis (AS) and to compare the AS patients with and without FM according to the disease activity, clinical and laboratory findings, and response to treatment. Patients and methods: Between September 2016 and September 2020, a total of 511 patients (312 males, 119 females; mean age: $43.0 \pm 11.2$ years; range, 18 to 77 years) who were diagnosed with AS were retrospectively analyzed. Age, sex, disease duration, disease onset age, and extra-articular findings were recorded. Medical treatments used by the patients for the treatment of AS and FM were noted. The erythrocyte sedimentation rate (ESR), C-reactive protein (CRP), human leukocyte antigen-B27 (HLA-B27) status, and Bath Ankylosing Spondylitis Disease Activity Index (BASDAI), Ankylosing Spondylitis Disease Activity Score (ASDAS) with ESR (ASDAS-ESR) and ASDAS-CRP values were recorded.

Results: The frequency of FM in AS patients was $23.2 \%$. Totally, $75.4 \%$ of the FM patients were female. The HLA-B27 positivity, extra-articular involvement frequency, disease duration, and acute phase reactants levels were similar between AS patients with and without FM $(p=0.118, p=0.154, p=0.829, p=0.113$, and $p=0.763$, respectively). The AS patients with $\mathrm{FM}$ had lower rates of achieving remission or low disease activity, compared to those without FM. The mean of all three disease activity scores between these two groups was also higher in the AS patients with FM ( $\mathrm{p}<0.001)$. The rate of use of biological therapy was significantly higher in the AS patients with FM than those without FM $(\mathrm{p}=0.037)$.

Conclusion: Since the treatment plan of AS is made based on the disease activity scores, unnecessary biological therapy may be initiated for patients or the biological therapies they use may be switched unnecessarily. Therefore, it should be kept in mind that FM may present with AS in patients who do not respond to treatment clinically, and this may be misinterpreted as treatment unresponsiveness.

Keywords: Ankylosing Spondylitis Disease Activity Score, ankylosing spondylitis, Bath Ankylosing Spondylitis Disease Activity Index, C-reactive protein, erythrocyte sedimentation rate, fibromyalgia syndrome, treatment.
\end{abstract}

Ankylosing spondylitis (AS), which primarily affects the spine and sacroiliac joints, is accepted as the prototype of spondylarthritis (SpA) diseases. ${ }^{[1]}$ If left untreated or not treated appropriately, it can cause disability and loss of workforce in the long term. Documenting the effects and consequences of the disease process and evaluating the effectiveness of treatment methods are critical for both the researchers and patients. Currently, disease evaluation indexes have been developed to eliminate the variability among the observers and to provide a standard assessment in determining the activity and functional status of

Corresponding author: Yunus Durmaz, MD. Karabük Eğitim ve Araştırma Hastanesi Fizik Tedavi ve Rehabilitasyon Kliniği, Romatoloji Bölümü, 78200 Karabük, Türkiye. e-mail: durmaz_y@hotmail.com 
the disease in AS and monitoring the response to treatment. ${ }^{[2]}$

The most commonly used disease activity evaluation index in AS is the Bath Ankylosing Spondylitis Disease Activity Index (BASDAI), which is almost entirely shaped by the patient's response to subjective questions. ${ }^{[3]}$ This drawback in BASDAI was handled by the Assessment of SpondyloArthritis international Society (ASAS) group, and they developed the Ankylosing Spondylitis Disease Activity Score (ASDAS) to increase the objectivity in the disease activity score ${ }^{[4]}$ Compared to the BASDAI, the main difference of ASDAS is the addition of laboratory findings.

Fibromyalgia (FM) syndrome is a chronic musculoskeletal disease of unknown cause, characterized by diffuse musculoskeletal pain and painful tender points in certain parts of the body ${ }^{[5]}$ The pooled prevalence of FM in patients with AS has been reported as $20 \% \cdot{ }^{[6]}$ It is not always easy to distinguish musculoskeletal pain caused by AS, which is the main prototype of SpA, and FM. In rheumatology practice, clinicians frequently encounter that FM accompanies inflammatory diseases. Fibromyalgia is a disease with a prevalence of 1 to $5 \% \cdot{ }^{[7,8]}$ This makes it one of the most common conditions that physiatrists and rheumatologists encounter. The most common typical symptoms of FM are widespread body pain, morning stiffness, fatigue, and sleep disturbance. ${ }^{[9,10]}$ Since these clinical symptoms can be often seen in AS, it is not always possible to differentiate the symptoms of the two diseases.

Additional symptom burden caused by FM may cause an increase in disease activity scores in patients with AS. In the present study, we aimed to investigate the association of FM in patients diagnosed with AS and to compare the AS patients with and without FM according to the disease activity, clinical and laboratory findings, and response to treatment.

\section{PATIENTS AND METHODS}

This single center, retrospective study was conducted at Karabük Training and Research Hospital, Division of Rheumatology, between September $1^{\text {st }}, 2016$ and September $1^{\text {st }}, 2020$. A total of 511 patients (312 males, 119 females; mean age: $43.0 \pm 11.2$ years; range, 18 to 77 years) who were diagnosed with AS according to the 1984 modified New York criteria were included. ${ }^{[11]}$ Among these patients, those diagnosed with FM according to the
1990 American College of Rheumatology (ACR) FM classification criteria were selected. ${ }^{[12]}$ Exclusion criteria were as follows: having missing file records, pregnant patients, patients under 18 years of age, patients with acute infection, and those with other rheumatological and endocrine diseases that may cause common musculoskeletal symptoms. Sociodemographic data such as age, sex, disease duration, and age at the time of disease onset, were recorded and extra-articular findings (e.g., uveitis, colitis, renal involvement) that may accompany AS were noted. Medical treatments (e.g., non-steroidal anti-inflammatory drugs [NSAIDs], sulfasalazine, biological treatments, duloxetine, pregabalin, and gabapentin) used by the patients for the treatment of AS and FM were documented. The erythrocyte sedimentation rate (ESR, $\mathrm{mm} / \mathrm{h}$ ), C-reactive protein (CRP, $\mathrm{mg} / \mathrm{L}$ ), human leukocyte antigen-B27 (HLA-B27) results of the patients and Bath Ankylosing Spondylitis Disease Activity Index (BASDAI), Ankylosing Spondylitis Disease Activity Score (ASDAS) with ESR (ASDAS-ESR) and ASDAS-CRP, which are the disease activity criteria in AS, were evaluated. The cut-off value for remission according to the BASDAI score was $<4$; however, remission notified by the health administration in Turkey is accepted as $<5$, also this cut-off value was used in the statistical analysis in our study. ${ }^{[3,13]}$ The cut-off value for ASDAS-ESR and ASDAS-CRP was $<1.3$ for remission, $<2.1$ for low disease activity, $\leq 3.5$ for high disease activity, and $>3.5$ for very high disease activity. ${ }^{[4]}$

A written informed consent was obtained from each patient. The study protocol was approved by the Karabuk University Faculty of Medicine Ethics Committee (No. 2020/353). The study was conducted in accordance with the principles of the Declaration of Helsinki.

\section{Statistical analysis}

Statistical analysis was performed using the IBM SPSS version 22.0 software (IBM Corp., Armonk, NY, USA). The skewness and kurtosis values and normality plots were used to evaluate whether the data were normally distributed. ${ }^{[14]}$ Descriptive data were expressed in mean \pm standard deviation (SD) for normally distributed data and in median (min-max) for non-normally distributed data. Categorical data were expressed in number and frequency. The Student t-test was used for comparison of normally distributed data, while the Mann-Whitney $U$ test was used for non-normally 


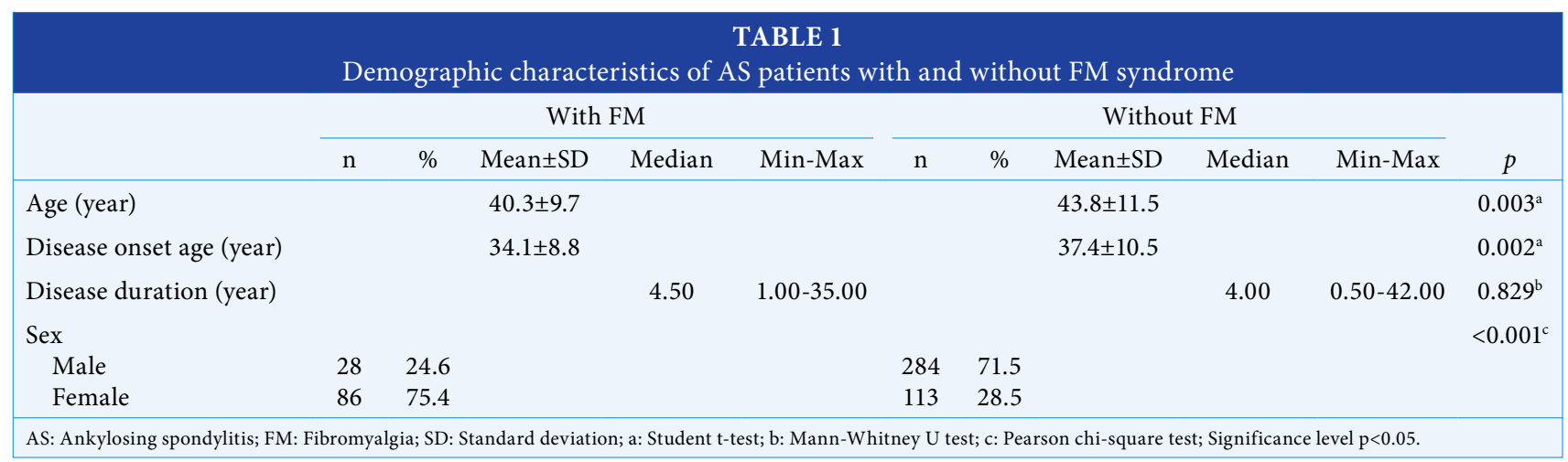

distributed data. The correlation between variables with normal distribution was analyzed using the Pearson correlation analysis. The correlation between variables that were not normally distributed was analyzed using the Spearman correlation test. The size of the correlation was interpreted as follows: 0.900 to $1.000(-0.900$ to -1.000$)=$ very high positive (negative) correlation; 0.700 to 0.900

\begin{tabular}{|c|c|c|c|c|c|c|c|c|c|c|c|}
\hline \multicolumn{12}{|c|}{ Comparison of clinical characteristic } \\
\hline & \multicolumn{5}{|c|}{ With FM } & \multicolumn{5}{|c|}{ Without FM } & \multirow[b]{2}{*}{$p$} \\
\hline & $\mathrm{n}$ & $\%$ & Mean \pm SD & Median & Min-Max & $\mathrm{n}$ & $\%$ & Mean \pm SD & Median & Min-Max & \\
\hline HLA-B27 & & & & & & & & & & & $0.118^{\mathrm{a}}$ \\
\hline Positive & 77 & 67.5 & & & & 236 & 59.4 & & & & \\
\hline Negative & 37 & 32.5 & & & & 161 & 40.6 & & & & \\
\hline Extra-articular involvement & & & & & & & & & & & $0.154^{\mathrm{a}}$ \\
\hline Yes & 18 & 15.8 & & & & 87 & 21.9 & & & & \\
\hline Non & 96 & 84.2 & & & & 310 & 78.1 & & & & \\
\hline Biological agents & & & & & & & & & & & $0.037^{\mathrm{a}}$ \\
\hline Yes & 62 & 54.4 & & & & 172 & 43.3 & & & & \\
\hline Non & 52 & 45.6 & & & & 225 & 56.7 & & & & \\
\hline BASDAI & & & $5.3 \pm 1.4$ & & & & & $2.1 \pm 1.4$ & & & $<0.001^{\mathrm{b}}$ \\
\hline ASDAS-ESR & & & $3.1 \pm 0.7$ & & & & & $2.0 \pm 0.8$ & & & $<0.001^{\mathrm{b}}$ \\
\hline ASDAS-CRP & & & $2.7 \pm 0.6$ & & & & & $1.6 \pm 0.7$ & & & $<0.001^{\mathrm{b}}$ \\
\hline BASDAI & & & & & & & & & & & $<0.001^{\mathrm{a}}$ \\
\hline Remission $(<4)$ & 17 & 14.9 & & & & 363 & 91.4 & & & & \\
\hline Active disease $(\geq 4)$ & 97 & 85.1 & & & & 34 & 8.6 & & & & \\
\hline BASDAI & & & & & & & & & & & $<0.001^{\mathrm{a}}$ \\
\hline Remission $(<5)$ & 55 & 48.2 & & & & 390 & 98.2 & & & & \\
\hline Active disease $(\geq 5)$ & 59 & 51.8 & & & & 7 & 1.8 & & & & \\
\hline ASDAS-ESR & & & & & & & & & & & $<0.001^{\mathrm{a}}$ \\
\hline $\begin{array}{l}\text { Remission or low disease } \\
\text { activity }(<2.1)\end{array}$ & 7 & 6.1 & & & & 221 & 55.7 & & & & \\
\hline $\begin{array}{l}\text { High or very high disease } \\
\text { activity }(\geq 2.2)\end{array}$ & 107 & 93.3 & & & & 176 & 44.2 & & & & \\
\hline ASDAS-CRP & & & & & & & & & & & $<0.001^{\mathrm{a}}$ \\
\hline $\begin{array}{l}\text { Remission or low disease } \\
\text { activity }(<2.1)\end{array}$ & 19 & 16.7 & & & & 317 & 79.8 & & & & \\
\hline $\begin{array}{l}\text { High or very high disease } \\
\text { activity }(\geq 2.2)\end{array}$ & 95 & 83.3 & & & & 80 & 20.2 & & & & \\
\hline $\operatorname{ESR}(\mathrm{mm} / \mathrm{h})$ & & & & 22.50 & $1.00-104.00$ & & & & 19.00 & $1.00-95.00$ & $0.113^{c}$ \\
\hline $\mathrm{CRP}(\mathrm{mg} / \mathrm{L})$ & & & & 2.47 & $0.04-25.00$ & & & & 2.45 & $0.02-57.00$ & $0.763^{c}$ \\
\hline
\end{tabular}


$(-0.700$ to -0.900$)=$ high positive (negative) correlation; 0.500 to $0.700(-0.500$ to -0.700$)=$ moderate positive (negative) correlation; 0.300 to $0.500(-0.300$ to $-0.500)=$ low positive (negative) correlation; 0.000 to $0.300(0.000$ to -0.300$)=$ negligible correlation. ${ }^{[15]}$ The chi-square test was used to analyze the difference between groups. Only the comparison of ASDAS-ESR cut-off values of the patients who received and did not receive treatment for FM was performed using the Fisher exact test, while the Pearson chi-square test was used for all other variables. A $p$ value of $<0.05$ was considered statistically significant.

\section{RESULTS}

The mean age at disease onset was $36.7 \pm 10.2$ years, and the median of the duration of the disease was 4 (range, 0.50 to 42 ) years. The median ESR of all patients included in the study was 20 (range, 1 to 104 ) $\mathrm{mm} / \mathrm{h}$, while the median CRP value was 2.45 (range, 0.02 to 57.00 ) $\mathrm{mg} / \mathrm{L}$. The HLA-B27 was found to be positive in 313 (61.3\%) of all patients.

While the mean BASDAI of all AS patients was 2.78 \pm 1.94 , the mean ASDAS-ESR was $2.28 \pm 0.86$ and the mean ASDAS-CRP was $1.83 \pm 0.82$. According to the remission rates of the patients included in the study based on the BASDAI scores, there were 380 (74.4\%) patients according to $<4$ cut-offs and 445 (87.1\%) patients according to $<5$ cut-offs. Based on the ASDAS-ESR scores, the number of patients with remission or low disease activity was 228 (44.6\%), while this number was $336(65.8 \%)$ according to the ASDAS-CRP scores.

\section{TABLE 3}

\begin{tabular}{|c|c|c|c|c|c|c|}
\hline & Corre & $\begin{array}{r}\text { ctivity sce } \\
\text { wi }\end{array}$ & $\begin{array}{l}\text { TABLE } \\
\text { s, ESR and C } \\
\text { or without Fl }\end{array}$ & $\begin{array}{l}\text { eactive protei } \\
\text { syndrome }\end{array}$ & in patients & \\
\hline & & BASDAI & ASDAS-ESR & ASDAS-CRP & $\operatorname{ESR}(\mathrm{mm} / \mathrm{h})$ & $\mathrm{CRP}(\mathrm{mg} / \mathrm{L})$ \\
\hline & BASDAI & & & & & \\
\hline & r & 1 & 0.727 & 0.806 & 0.061 & 0.079 \\
\hline & $\mathrm{p}$ & & $<0.001^{\mathrm{a}}$ & $<0.001^{\mathrm{a}}$ & $0.521^{\mathrm{b}}$ & $0.403^{\mathrm{b}}$ \\
\hline & ASDAS-ESR & & & & & \\
\hline & $\mathrm{r}$ & 0.727 & 1 & 0.785 & 0.669 & 0.382 \\
\hline 空 & $\mathrm{p}$ & $<0.001^{\mathrm{a}}$ & & $<0.001^{\mathrm{a}}$ & $<0.001^{\mathrm{b}}$ & $<0.001^{\mathrm{b}}$ \\
\hline 点 & ASDAS-CRP & & & & & \\
\hline 3 & $\mathrm{r}$ & 0.806 & 0.785 & 1 & 0.314 & 0.544 \\
\hline$\vec{\Xi}$ & $\mathrm{p}$ & $<0.001^{\mathrm{a}}$ & $<0.001^{\mathrm{a}}$ & & $0.001^{\mathrm{b}}$ & $<0.001^{\mathrm{b}}$ \\
\hline है & $\operatorname{ESR}(\mathrm{mm} / \mathrm{h})$ & & & & & \\
\hline & $\mathrm{r}$ & 0.061 & 0.669 & 0.314 & 1 & 0.433 \\
\hline & $\mathrm{p}$ & $0.521^{\mathrm{b}}$ & $<0.001^{\mathrm{b}}$ & $0.001^{\mathrm{b}}$ & & $<0.001^{\mathrm{b}}$ \\
\hline & CRP (mg/L) & & & & & \\
\hline & $\mathrm{r}$ & 0.079 & 0.382 & 0.544 & 0.433 & 1 \\
\hline & $\mathrm{p}$ & $0.403^{\mathrm{b}}$ & $<0.001^{\mathrm{b}}$ & $<0.001^{\mathrm{b}}$ & $<0.001^{\mathrm{b}}$ & \\
\hline & BASDAI & & & & & \\
\hline & $\mathrm{r}$ & 1 & 0.764 & 0.841 & 0.265 & 0.214 \\
\hline & $\mathrm{p}$ & & $<0.001^{\mathrm{a}}$ & $<0.001^{\mathrm{a}}$ & $<0.001^{\mathrm{b}}$ & $<0.001^{\mathrm{b}}$ \\
\hline & ASDAS-ESR & & & & & \\
\hline & r & 0.764 & 1 & 0.800 & 0.769 & 0.447 \\
\hline$\stackrel{L}{ \pm}$ & $\mathrm{p}$ & $<0.001^{\mathrm{a}}$ & & $<0.001^{\mathrm{a}}$ & $<0.001^{\mathrm{b}}$ & $<0.001^{\mathrm{b}}$ \\
\hline$\stackrel{\Xi}{\Phi}$ & ASDAS-CRP & & & & & \\
\hline$\frac{1}{3}$ & $\mathrm{r}$ & 0.841 & 0.800 & 1 & 0.432 & 0.561 \\
\hline 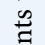 & $\mathrm{p}$ & $<0.001^{\mathrm{a}}$ & $<0.001^{\mathrm{a}}$ & & $<0.001^{\mathrm{b}}$ & $<0.001^{\mathrm{b}}$ \\
\hline 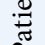 & $\operatorname{ESR}(\mathrm{mm} / \mathrm{h})$ & & & & & \\
\hline & r & 0.265 & 0.769 & 0.432 & 1 & 0.520 \\
\hline & $\mathrm{p}$ & $<0.001^{\mathrm{b}}$ & $<0.001^{\mathrm{b}}$ & $<0.001^{\mathrm{b}}$ & & $<0.001^{\mathrm{b}}$ \\
\hline & CRP (mg/L) & & & & & \\
\hline & r & 0.214 & 0.447 & 0.561 & 0.520 & 1 \\
\hline & $\mathrm{p}$ & $<0.001^{\mathrm{b}}$ & $<0.001^{\mathrm{b}}$ & $<0.001^{\mathrm{b}}$ & $<0.001^{\mathrm{b}}$ & \\
\hline
\end{tabular}


All patients included in the study were using NSAIDs, as needed. Of the patients, 193 (37.8\%) were using sulfasalazine, 110 (21.5\%) adalimumab, 53 (10.4\%) etanercept, 30 (5.9\%) infliximab, 21 (4.1\%) certolizumab, 13 (2.5\%) secukinumab, and seven (1.4\%) golimumab. While 277 of the patients (54.2\%) did not use any biological therapy, there was a history of using one biological therapy in 178 (34.8\%), two in 47 (9.2\%), three in seven (1.4\%), and four in two (0.4\%). There was an extra-articular finding in 105 (20.5\%) of the patients. Of these patients, $83(16.2 \%)$ were uveitis, 19 (3.7\%) were inflammatory colitis, two $(0.4 \%)$ were pulmonary involvement, and one $(0.2 \%)$ was renal amyloidosis.

Overall, FM was detected in 114 of the patients (23.2\%) with AS. Twenty-eight (24.6\%) of FM patients were male. When the patients with and without FM were compared in terms of sex, there was a significant difference $(p<0.001)$. Demographic characteristics of AS patients with and without FM are shown in Table 1 , and the comparison of their clinical characteristics is summarized in Table 2.

Two hundred thirty-four (45.7\%) of all patients with AS were receiving biological therapy. Among these,
33 (53.2\%) of the AS patients with FM did not need a switch until now, while 29 (46.8\%) patients needed two or more biological therapy switches. In patients with AS without FM, this number was 145 (84.3\%) and 27 (15.7\%), respectively. When the AS patients with and without FM were evaluated in terms of the number of biological therapy switches, a statistically significant difference was found $(\mathrm{p}<0.001)$.

The BASDAI scores were high positively correlated with the ASDAS-ESR and ASDAS-CRP scores in AS patients accompanied by FM, while these scores were not correlated with ESR and CRP values $(\mathrm{p}<0.001, \mathrm{r}=0.727 ; \mathrm{p}<0.001, \mathrm{r}=0.806 ; \mathrm{p}=0.521$, $\mathrm{r}=0.061, \mathrm{p}=0.403, \mathrm{r}=0.079$, respectively). Table 3 shows the correlation of disease activity scores, ESR, and CRP values in AS patients with and without FM.

Seventy $(61.4 \%)$ of the patients with FM were using a drug for the treatment of FM. The mean BASDAI of these patients who received treatment for FM was $5.41 \pm 1.19$, while the mean BASDAI of those who did not receive treatment was $5.08 \pm 1.56$. There was no statistically significant difference between using/not using FM treatment for BASDAI mean scores in patients with FM

\begin{tabular}{|c|c|c|c|c|c|c|c|c|c|c|c|}
\hline \multicolumn{12}{|c|}{$\begin{array}{c}\text { TABLE } 4 \\
\text { Association between disease activity scores and whether or not to use treatment for FM among AS patients }\end{array}$} \\
\hline & \multicolumn{5}{|c|}{ FM treatment (Yes) } & \multicolumn{5}{|c|}{ FM treatment $(\mathrm{No})$} & \multirow[b]{2}{*}{$p$} \\
\hline & $\mathrm{n}$ & $\%$ & Mean \pm SD & Median & Min-Max & $\mathrm{n}$ & $\%$ & Mean \pm SD & Median & Min-Max & \\
\hline BASDAI & & & & & & & & & & & $0.063^{\mathrm{a}}$ \\
\hline Remission $(<4)$ & 7 & 10.0 & & & & 10 & 14.9 & & & & \\
\hline Active disease $(\geq 4)$ & 63 & 90.0 & & & & 34 & 77.3 & & & & \\
\hline BASDAI & & & & & & & & & & & $0.930^{\mathrm{a}}$ \\
\hline Remission $(<5)$ & 34 & 48.6 & & & & 21 & 47.7 & & & & \\
\hline Active disease $(\geq 5)$ & 36 & 51.4 & & & & 23 & 52.3 & & & & \\
\hline ASDAS-ESR & & & & & & & & & & & $0.257^{\mathrm{b}}$ \\
\hline $\begin{array}{l}\text { Remission or low } \\
\text { disease activity }(<2.1)\end{array}$ & 3 & 4.3 & & & & 4 & 9.1 & & & & \\
\hline $\begin{array}{l}\text { High or very high } \\
\text { disease activity }(\geq 2.2)\end{array}$ & 67 & 95.7 & & & & 40 & 90.9 & & & & \\
\hline ASDAS-CRP & & & & & & & & & & & $0.390^{\mathrm{a}}$ \\
\hline $\begin{array}{l}\text { Remission or low disease } \\
\text { activity }(<2.1)\end{array}$ & 10 & 14.3 & & & & 9 & 20.5 & & & & \\
\hline $\begin{array}{l}\text { High or very high disease } \\
\text { activity }(\geq 2.2)\end{array}$ & 60 & 85.7 & & & & 35 & 79.5 & & & & \\
\hline BASDAI & & & $5.4 \pm 1.2$ & & & & & $5.1 \pm 1.6$ & & & $0.218^{c}$ \\
\hline ASDAS-ESR & & & $3.1 \pm 0.7$ & & & & & $3.1 \pm 0.6$ & & & $0.722^{c}$ \\
\hline ASDAS-CRP & & & $2.7 \pm 0.6$ & & & & & $2.6 \pm 0.7$ & & & $0.706^{c}$ \\
\hline ESR (mm/hr.) & & & & 21.00 & $1.00-104.00$ & & & & 24.00 & $6.00-44.00$ & $0.465^{\mathrm{d}}$ \\
\hline $\mathrm{CRP}(\mathrm{mg} / \mathrm{L})$ & & & & 2.15 & $0.04-25.00$ & & & & 2.70 & $0.05-18.00$ & $0.259^{\mathrm{d}}$ \\
\hline
\end{tabular}

FM: Fibromyalgia; Yes: FM treatment in patients receiving biological therapy; No: FM treatment in patients not receiving biological therapy; AS: Ankylosing spondylitis; SD: Standard deviation; BASDAI: Bath Ankylosing Spondylitis Disease Activity Index; ASDAS: Ankylosing Spondylitis Disease Activity Score; ESR: Erythrocyte sedimentation rate; CRP: C-reactive protein; a: Pearson $\chi^{2}$ test; b: Fisher's exact test; c: Student t-test; d: Mann-Whitney U test; Significance level $\mathrm{p}<0.05$. 


\section{TABLE 5}

Comparison of disease activity scores in patients with and without FM syndrome in AS patients using and not using biological therapy

\begin{tabular}{|c|c|c|c|c|c|c|c|c|c|c|c|c|}
\hline & \multicolumn{5}{|c|}{ Patients with FM } & \multicolumn{5}{|c|}{ Patients without FM } & \multirow[b]{2}{*}{$p$} \\
\hline & & $\mathrm{n}$ & $\%$ & Mean \pm SD & Median & Min-Max & $\mathrm{n}$ & $\%$ & Mean \pm SD & Median & Min-Max & \\
\hline \multirow{17}{*}{ 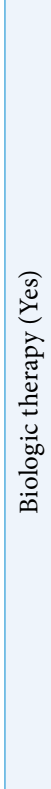 } & BASDAI & & & $5.2 \pm 1.6$ & & & & & $1.5 \pm 1.5$ & & & $<0.001^{\circ}$ \\
\hline & ASDAS-ESR & & & $3.0 \pm 0.7$ & & & & & $1.8 \pm .0 .8$ & & & $<0.001^{\circ}$ \\
\hline & ASDAS-CRP & & & $2.6 \pm 0.7$ & & & & & $1.4 \pm 0.7$ & & & $<0.001^{\circ}$ \\
\hline & $\operatorname{ESR}(\mathrm{mm} / \mathrm{h})$ & & & & 20.00 & $1.00-63.00$ & & & & 18.50 & $1.00-95.00$ & $0.402^{\mathrm{b}}$ \\
\hline & CRP (mg/L) & & & & 2.45 & $0.05-18.00$ & & & & 2.26 & $0.02-57.00$ & $0.578^{\mathrm{b}}$ \\
\hline & BASDAI & & & & & & & & & & & $<0.001$ \\
\hline & Remission $(<4)$ & 13 & 21.0 & & & & 160 & 93.0 & & & & \\
\hline & Active disease $(\geq 4)$ & 49 & 79.0 & & & & 12 & 7.0 & & & & \\
\hline & BASDAI & & & & & & & & & & & $<0.001$ \\
\hline & Remission $(<5)$ & 31 & 50.0 & & & & 169 & 98.3 & & & & \\
\hline & Active disease $(\geq 5)$ & 31 & 50.0 & & & & 3 & 1.7 & & & & \\
\hline & ASDAS-ESR & & & & & & & & & & & $<0.001^{\circ}$ \\
\hline & $\begin{array}{l}\text { Remission or low disease } \\
\text { activity }(<2.1)\end{array}$ & 7 & 11.3 & & & & 116 & 67.4 & & & & \\
\hline & $\begin{array}{l}\text { High or very high disease } \\
\text { activity }(\geq 2.2)\end{array}$ & 55 & 88.7 & & & & 56 & 32.6 & & & & \\
\hline & ASDAS-CRP & & & & & & & & & & & $<0.001^{\circ}$ \\
\hline & $\begin{array}{l}\text { Remission or low disease } \\
\text { activity }(<2.1)\end{array}$ & 13 & 21.0 & & & & 145 & 84.3 & & & & \\
\hline & $\begin{array}{l}\text { High or very high disease } \\
\text { activity }(\geq 2.2)\end{array}$ & 49 & 79.0 & & & & 27 & 15.7 & & & & \\
\hline \multirow{17}{*}{ 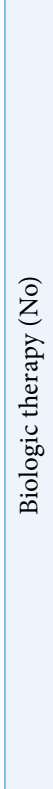 } & BASDAI & & & $5.4 \pm 1.1$ & & & & & $2.5 \pm 1.2$ & & & $<0.001^{\circ}$ \\
\hline & ASDAS-ESR & & & $3.2 \pm 0.6$ & & & & & $2.2 \pm 0.7$ & & & $<0.001^{\mathrm{a}}$ \\
\hline & ASDAS-CRP & & & $2.7 \pm 0.5$ & & & & & $1.2 \pm 0.7$ & & & $<0.001^{\circ}$ \\
\hline & $\operatorname{ESR}(\mathrm{mm} / \mathrm{h})$ & & & & 24.5 & $4.00-104.00$ & & & & 20.00 & $3.00-79.00$ & $0.093^{\mathrm{b}}$ \\
\hline & $\mathrm{CRP}(\mathrm{mg} / \mathrm{L})$ & & & & 2.47 & $0.04-25.00$ & & & & 2.51 & $0.18-47.00$ & $0.889^{\mathrm{b}}$ \\
\hline & BASDAI & & & & & & & & & & & $<0.001^{\circ}$ \\
\hline & Remission $(<4)$ & 4 & 7.7 & & & & 203 & 90.2 & & & & \\
\hline & Active disease $(\geq 4)$ & 48 & 92.3 & & & & 22 & 9.8 & & & & \\
\hline & BASDAI & & & & & & & & & & & $<0.001^{\circ}$ \\
\hline & Remission $(<5)$ & 24 & 46.2 & & & & 221 & 98.2 & & & & \\
\hline & Active disease $(\geq 5)$ & 28 & 53.8 & & & & 4 & 1.8 & & & & \\
\hline & ASDAS-ESR & & & & & & & & & & & $<0.001^{\circ}$ \\
\hline & $\begin{array}{l}\text { Remission or low disease } \\
\text { activity }(<2.1)\end{array}$ & 0 & 0.0 & & & & 105 & 46.7 & & & & \\
\hline & $\begin{array}{l}\text { High or very high disease } \\
\text { activity }(\geq 2.2)\end{array}$ & 52 & 100.0 & & & & 120 & 53.3 & & & & \\
\hline & ASDAS-CRP & & & & & & & & & & & $<0.001^{\circ}$ \\
\hline & $\begin{array}{l}\text { Remission or low disease } \\
\text { activity }(<2.1)\end{array}$ & 6 & 11.5 & & & & 172 & 76.4 & & & & \\
\hline & $\begin{array}{l}\text { High or very high disease } \\
\text { activity }(\geq 2.2)\end{array}$ & 46 & 88.5 & & & & 53 & 23.6 & & & & \\
\hline
\end{tabular}

FM: Fibromyalgia; Yes: FM treatment in patients receiving biological therapy; No: FM treatment in patients not receiving biological therapy; AS: Ankylosing spondylitis; SD: Standard deviation; BASDAI: Bath Ankylosing Spondylitis Disease Activity Index; ASDAS: Ankylosing Spondylitis Disease Activity Score; ESR: Erythrocyte sedimentation rate; ; CRP: C-reactive protein; a: Student t-test; b: Mann-Whitney U test; c: Pearson chi-square test; Significance level p $<0.05$.

among AS patients $(\mathrm{p}=0.218)$. Table 4 shows the distribution of AS patients with FM and the use of FM treatment and their disease activity scores. Table 5 shows the comparison of disease activity scores in AS patients with and without FM using and not using biological therapy.

\section{DISCUSSION}

In our study, the frequency of FM accompanying AS was $23.2 \%$, similar to the literature. We found that HLA-B27 positivity, extra-articular involvement frequency, disease duration and acute phase reactants levels in AS patients with FM were similar to the 
patients without FM. In addition, the AS patients with FM had lower rates of achieving remission or low disease activity, compared to those without FM. Similarly, the mean of all three disease activity scores between these two groups was higher in these patients. The rate of use of biological therapy was also significantly higher in the AS patients with FM compared to those without FM.

In the literature, the association of these inflammatory diseases with FM has been the subject of interest for many researchers. In an updated meta-analysis including 26 cross-sectional studies involving RA patients, the pooled prevalence of FM was $21 \% \cdot{ }^{[16]}$ Also, the prevalence of FM reported in patients with psoriatic arthritis ranges from 10 to 27\%. ${ }^{[16]}$ Again, in the literature, it has been reported that 19 to $29 \%$ of patients with AS and 19 to $25 \%$ of patients with non-radiographic-axial SpA meet FM criteria. ${ }^{[17,18]}$ In our study, the frequency of FM accompanied by AS was $23.2 \%$, similar to the literature. A total of $75.4 \%$ of the FM patients were female, once again highlighting the fact that FM is a female-dominant disease. ${ }^{[19-22]}$

The BASDAI, which is used in the evaluation of AS disease severity, is a self-assessment scale based on a scoring based only on the burden of clinical symptoms and without a laboratory part. This may be affected by the additional symptom burden caused by FM in a patient with AS, and BASDAI scores may increase. In addition, all questions other than the questions about morning stiffness evaluated in BASDAI can be seen in the FM presentation. Only morning stiffness lasts much shorter in FM compared to inflammatory diseases.

In a meta-analysis by Duffield et al., ${ }^{[16]}$ five studies were evaluated comparing AS patients with and without FM. Similar to our study, the BASDAI scores were higher in the AS patients with FM. Another aspect of the meta-analysis of Duffield et al., ${ }^{[16]}$ similar to our study, is that AS patients with and without FM had similar ESR and CRP levels. In another study, although the mean BASDAI score was found higher in patients with axial SpA and FM, compared to patients with only axial SpA, the $p$ values of the study were not reported. ${ }^{[23]}$ Similar to our study, Wach et al. ${ }^{[24]}$ found that BASDAI scores were significantly higher in patients with SpA and FM, compared to patients with only SpA in their study. Consistent with our study, they found the duration of illness, CRP values, HLA-B27 positivity, extra-articular involvement similar between the SpA patients with and without FM. The part of this study that was not similar to our study results was that ASDAS-CRP values and age of the patients were found similar, when the SpA patients with and without FM were compared. In another study, Almodóvar et al. ${ }^{[21]}$ compared patients with AS with and without FM, and they found the frequency of extra-articular findings, disease onset age, disease duration, CRP value, and HLA-B27 positivity to be similar between the patient groups.

In our study, the rate of use of biological therapy was significantly higher in AS patients with FM than those without FM. Contrary to the results of our study, Wach et al. ${ }^{[24]}$ found the use of biological therapy similar between the SpA patients with and without FM. Again, contrary to our study, Almodóvar et al. ${ }^{[21]}$ found the use of biological therapy similar in AS patients with and without FM.

In the present study, according to the number of switches in biological therapy, we found much higher rates in AS patients with FM than those without FM. To the best of our knowledge, there is no study evaluating the number of biological therapy switches in similar study groups in the literature. In a study by Macfarlane et al., ${ }^{[25]} 1,757$ patients with axial SpA were examined retrospectively and $22.1 \%$ of them met the FM criteria. Similar to our study, the patients who met the FM criteria were found to have BASDAI scores higher than those with only axial SpA; however, at the end of 12 months, no significant difference was observed between the groups in terms of the BASDAI, ASAS-20, or ASAS-40 response criteria. On the other hand, Moltó et al., ${ }^{[26]}$ supporting the results of our study, showed that the response to biological therapy was lower in AS patients with FM at 12 months compared to AS patients without FM (although this low response did not reach statistical significance for BASDAI, it reached statistical significance for ASAS-20 and ASAS-40 responses). This may cause clinicians to make unncessary switch decisions in case of unresponsiveness to biological therapy.

In our study, all three disease activity scores were highly and positively correlated with each other in patients with AS with or without FM. Similar to our study, in the literature, these disease activity scores were positively correlated in patients with SpA. ${ }^{[20,23]}$ Although the acute phase reactants were taken into account while calculating both ASDAS-ESR and ASDAS-CRP, the correlation between them was moderate in AS patients with FM in our study, and the correlation between ESR and ASDAS-ESR was high in AS patients without FM. We believe that 
the main reason for the lack of a high correlation in AS patients with FM is the predominance of clinical symptoms in the ASDAS, which is due to the fact that the self-reported results of the patients are not completely objective. Another result that supports this is that the acute phase reactant levels of the patients did not significantly differ between the groups, although the activity scores of all three diseases (BASDAI, ASDAS-ESR, and ASDAS-CRP) were significantly higher in AS patients with FM than AS patients without FM, even if they used biological therapy. In other words, while there was no significant difference between laboratory activities, the fact that the disease activity scores are still high in AS patients with FM may be due to the increase in the disease activity scores of FM-related symptoms.

In the current study, we also examined AS patients who received medical treatment for FM. As a result of our study, $61.4 \%$ of FM patients received treatment for FM. However, regardless of receiving treatment, the mean of all three disease activity scores (BASDAIASDAS-ESR, ASDAS-CRP) of these patients with FM were similar, and the rates of being in remission or having an active disease calculated according to the disease score results were also similar. This finding indicates that current FM therapy is not very successful in AS patients with FM.

The main limitation of our study is that it has a retrospective design. Our study results should be supported by further prospective follow-up studies. The main strength of our study is that we were able to include a sufficient number of patients in our study, since we had a detailed patient registry. We believe that these results can contribute to daily rheumatology practice.

In conclusion, in the presence of FM accompanied by AS, all the disease activity measurement tools currently available seem to be insufficient to guide us as much as desired. Since the treatment plan of AS is made based on these tools, unnecessary biological therapy may be initiated for patients or the biological therapies they use may be switched unnecessarily. Therefore, it should be kept in mind that FM may present with AS in patients who do not respond to treatment clinically, and this may be misinterpreted as treatment unresponsiveness.

\section{Declaration of conflicting interests}

The authors declared no conflicts of interest with respect to the authorship and/or publication of this article.
Funding

The authors received no financial support for the research and/or authorship of this article.

\section{REFERENCES}

1. Gran JT, Husby G. Ankylosing spondylitis in women. Semin Arthritis Rheum 1990;19:303-12.

2. Haywood KL, Garratt AM, Jordan K, Dziedzic K, Dawes PT. Spinal mobility in ankylosing spondylitis: Reliability, validity and responsiveness. Rheumatology (Oxford) 2004;43:750-7.

3. Garrett S, Jenkinson T, Kennedy LG, Whitelock H, Gaisford $\mathrm{P}$, Calin A. A new approach to defining disease status in ankylosing spondylitis: The Bath Ankylosing Spondylitis Disease Activity Index. J Rheumatol 1994;21:2286-91.

4. Machado P, Landewé R, Lie E, Kvien TK, Braun J, Baker $\mathrm{D}$, et al. Ankylosing Spondylitis Disease Activity Score (ASDAS): Defining cut-off values for disease activity states and improvement scores. Ann Rheum Dis 2011;70:47-53.

5. Bellato E, Marini E, Castoldi F, Barbasetti N, Mattei L, Bonasia DE, et al. Fibromyalgia syndrome: etiology, pathogenesis, diagnosis, and treatment. Pain Res Treat 2012;2012:426130.

6. Zhao SS, Duffield SJ, Goodson NJ. The prevalence and impact of comorbid fibromyalgia in inflammatory arthritis. Best Pract Res Clin Rheumatol 2019;33:101423.

7. Yunus MB, Masi AT. Juvenile primary fibromyalgia syndrome. A clinical study of thirty-three patients and matched normal controls. Arthritis Rheum 1985;28:138-45.

8. Yunus MB, Holt GS, Masi AT, Aldag JC. Fibromyalgia syndrome among the elderly. Comparison with younger patients. J Am Geriatr Soc 1988;36:987-95.

9. Yunus MB, Masi AT, Aldag JC. A controlled study of primary fibromyalgia syndrome: Clinical features and association with other functional syndromes. J Rheumatol Suppl 1989;19:62-71.

10. Leavitt F, Katz RS, Golden HE, Glickman PB, Layfer LF. Comparison of pain properties in fibromyalgia patients and rheumatoid arthritis patients. Arthritis Rheum 1986;29:775-81.

11. van der Linden S, Valkenburg HA, Cats A. Evaluation of diagnostic criteria for ankylosing spondylitis. A proposal for modification of the New York criteria. Arthritis Rheum 1984;27:361-8.

12. Wolfe F, Smythe HA, Yunus MB, Bennett RM, Bombardier C, Goldenberg DL, et al. The American College of Rheumatology 1990 criteria for the classification of fibromyalgia. Report of the Multicenter Criteria Committee. Arthritis Rheum 1990;33:160-72.

13. Instructions for healthcare applications. Social Security Institution in Turkey. 2020. Available at: https://www. resmigazete.gov.tr/eskiler/2013/03/20130324-3.pdf.

14. Hair J, Black W, Babin B, Anderson R, Tatham R. Multivariate Data Analysis. Essex: Pearson Education Limited; 2013.

15. Hinkle DE, Wiersma W, Jurs SG. Applied statistics for the behavioral sciences. Houghton Mifflin College Division; 2003. 
16. Duffield SJ, Miller N, Zhao S, Goodson NJ. Concomitant fibromyalgia complicating chronic inflammatory arthritis: A systematic review and meta-analysis. Rheumatology (Oxford) 2018;57:1453-60.

17. Baraliakos X, Regel A, Kiltz U, Menne HJ, Dybowski F, Igelmann $\mathrm{M}$, et al. Patients with fibromyalgia rarely fulfil classification criteria for axial spondyloarthritis. Rheumatology (Oxford) 2018;57:1541-7.

18. Macfarlane GJ, Barnish MS, Pathan E, Martin KR, Haywood KL, Siebert S, et al. Co-occurrence and characteristics of patients with axial spondyloarthritis who meet criteria for fibromyalgia: Results from a UK National register. Arthritis Rheumatol 2017;69:2144-50.

19. Häuser W, Ablin J, Fitzcharles MA, Littlejohn G, Luciano JV, Usui C, et al. Fibromyalgia. Nat Rev Dis Primers 2015;1:15022.

20. Haliloglu S, Carlioglu A, Akdeniz D, Karaaslan Y, Kosar A. Fibromyalgia in patients with other rheumatic diseases: Prevalence and relationship with disease activity. Rheumatol Int 2014;34:1275-80.

21. Almodóvar R, Carmona L, Zarco P, Collantes E, González $\mathrm{C}$, Mulero J, et al. Fibromyalgia in patients with ankylosing spondylitis: Prevalence and utility of the measures of activity, function and radiological damage. Clin Exp Rheumatol 2010;28(6 Suppl 63):S33-9.

22. Demiral S, Çakır T, Tugrul T, Subaşı V. Coexisting of fibromyalgia syndrome and ankylosing spondylitis. Acta Medica Mediterranea, 2013;29:827-33.

23. Salaffi F, De Angelis R, Carotti M, Gutierrez M, SarziPuttini P, Atzeni F. Fibromyalgia in patients with axial spondyloarthritis: Epidemiological profile and effect on measures of disease activity. Rheumatol Int 2014;34:1103-10.

24. Wach J, Letroublon MC, Coury F, Tebib JG. Fibromyalgia in spondyloarthritis: Effect on disease activity assessment in clinical practice. J Rheumatol 2016;43:2056-63.

25. Macfarlane GJ, MacDonald RIR, Pathan E, Siebert $\mathrm{S}$, Gaffney K, Choy E, et al. Influence of co-morbid fibromyalgia on disease activity measures and response to tumour necrosis factor inhibitors in axial spondyloarthritis: Results from a UK national register. Rheumatology (Oxford) 2018;57:1982-90.

26. Moltó A, Etcheto A, Gossec L, Boudersa N, Claudepierre P, Roux N, et al. Evaluation of the impact of concomitant fibromyalgia on TNF alpha blockers' effectiveness in axial spondyloarthritis: Results of a prospective, multicentre study. Ann Rheum Dis 2018;77:533-40. 